\title{
Further field observations in the Ivisârtoq region of southern West Greenland
}

\author{
Mark Brewer, Brian Chadwick, Kenneth Coe and Julia F. W. Park
}

Mapping by the Exeter team was begun in 1981 and in three field seasons six geologists have been engaged for a total of $14 \mathrm{man} / \mathrm{seasons}$. This is a sad comparison with the Buksefjorden project which, though covering a comparable area, benefitted from an investment of $24 \mathrm{man} / \mathrm{seasons}$ spread over six field seasons. Geologists mapping the Ivisârtoq area had the benefit of earlier reconnaissance maps and reports, but it is felt very strongly that the complexity of the ground and the degree of outcrop on the one hand, and the enormous significance of a proper interpretation on the other, justify a more intensive investigation. Mapping of the Ivisârtoq sheet was scheduled for completion in 1983 but inclement weather meant that some small parts of the area were not mapped. However, sampling programmes for certain specific problems were satisfactorily concluded. To keep this report as short as possible, it concentrates mainly on new and significant observations and interpretations made in the 1983 field season, so that some important aspects of the geology of the area are not mentioned here.

\section{Field relations between quartzo-feldspathic rocks of Nunatarssuaq}

In the south-east of Nunatarssuaq there is an area of grey multiphase banded gneisses containing a large number of amphibolite strips concordant with the gneiss fabric. Feldspar clots with and without rims are present in some which are comparable with the $\mathrm{B}$ and $\mathrm{C}$ type Ameralik dykes described by Chadwick (1981). In one instance there is a discordant amphibolite dyke in an enclave of banded amphibolite. This suggests that the host is Nûk gneiss rather than Amîtsoq. An Amîtsoq age would mean that the amphibolite dyke was an Inaluk dyke (Nutman, 1982) for which there is no further evidence. This adds further to the problem of identifying similar dykes in both generations of gneiss (Brewer et al., 1983; and see below).Verification of the age of the gneisses depends on further isotope investigations which are in hand.

To the west of Iluliartô there is an abundance of concordant, homogeneous, amphibolite strips which can be traced up to $100 \mathrm{~m}$ in a multiphase gneiss. These may be derived from dykes which have been rotated into parallelism with the gneiss fabric, or may represent rafting of supracrustal rocks during the intrusion of the gneiss precursor. No evidence from the enclaves (e.g. iron formation) has been found to suggest an origin older than Nûk. Two or three phases of Nûk gneiss are present in Nunatarssuaq, the last of which may have been formed during a separate magmatic event later than the Nûk. Equivalents of Nûk 2 (Coe \& Robertson, 1982) are the earliest and most prolific phase of gneiss in Nunatarssuaq. These are multiphase, pegmatite-banded gneisses of tonalitic composition which are in turn intruded by pale grey fine- to medium-grained granitic-granodioritic gneisses that have a poorly developed $S$ fabric. They contain a network of thin pegmatite seams which in some cases are folded. Generally the relationships between these two groups of gneiss are 
uncertain either because of poor exposure in valley floors or because of subsequent intrusion by rocks of the Qôrqut granite complex.

The third group of gneisses which may be of Nûk affinity are strongly foliated, medium- to coarse-grained mafic tonalites with up to $40 \%$ biotite. They contain amphibolite strips which may represent dykes or supracrustal rafts like those in the gneisses of south-east Nunatarssuaq. They outcrop south of Narssaq and in a synformal core in central Nunatarssuaq. Their intrusion must be pre-tectonic since they have folded $S$ fabrics and are intruded by underformed Qôrqut granites and pegmatites.

A post-Nûk phase of medium-grained, weakly foliated tonalites and trondhjemites is represented in the Narssaq region. The outcrops are in a poorly exposed area so that contact relationships are not clear. Compositional banding is characteristic of this group of granitic rocks. Unmodified blocks up to $5 \mathrm{~m}$ in length of banded gneiss are locally abundant within the tonalite. This xenolithic complex is generally intruded by Qôrqut granites and pegmatites.

A late group of fine- to medium-grained biotite granites, commonly with a well developed foliation parallel to the margin owing to preferential alignment of micas, occurs as sheets up to $20 \mathrm{~m}$ thick. Preliminary whole rock $\mathrm{Rb}-\mathrm{Sr}$ investigations yield a $2624 \pm 78 \mathrm{Ma}$ age. The sheets are generally steeply dipping, rather than flat-lying like the rocks of the Qorqut complex in Nunatarssuaq.

Further $\mathrm{Rb}-\mathrm{Sr}$ isotope investigations on rocks from west Nunatarssuaq have yielded a $2572 \pm 54 \mathrm{Ma}$ age for rocks of the Qôrqut granite complex. These are polyphase and outcrop over large areas. Two or three phases of granite and pegmatite can be recognised. Coarsegrained, pale grey granites with hypidiomorphic granular textures occur as massive bodies in a few areas. They generally have vertical contacts and contain few if any xenoliths of the host rock. Paler granites and grey biotite granites are also recognised, the latter being fine grained and commonly possessing a poorly developed fabric parallel to the margin, whereas the former is generally inhomogeneous. They are usually intruded as a shallow dipping sheeted complex with a few risers also present varying in thickness from $1 \mathrm{~m}$ to more than 20 $\mathrm{m}$. The pale granites are generally very coarse grained and their inhomogeneity is due to mafic schlieren with a varied spacing depending on the nature of the original gneiss. These schlieren fabrics were produced from mafic concentrations, either biotite-rich bands from the gneiss, or amphibolitic from supracrustal material or dykes. A coarsening of the fabric due to quartz/feldspar blastesis associated with an episode of partial melting resulted in the granitisation of the older quartzo-feldspathic rocks. Transgressive contacts between gneiss and the schlieric granite are present. Relict gneiss structures such as banding and folding are preserved, but obviously their original textures were destroyed during this process. Blocks of unmodified gneiss are commonly present in this granite, and this possibly represents a lesser degree of partial melting. The structures in the gneiss can be traced through the granite, but in less detail. The central region of Nunatarssuaq is composed mainly of this type of granitegneiss relationship and appears to be related to an area of general uplift.

Late pegmatites, some containing euhedral allanite crystals up to $4 \mathrm{~cm}$ long and often associated with magnetite, and some garnetiferous, form a network of vertical and horizontal veins and sheets which, in cliff sections, form spectacular veined systems through the supracrustal belts. There are both primary and secondary fabrics in the pegmatites. Pegmatite sheets discordant to the late phase of tonalite gneisses in central Nunatarssuaq are banded; mica concentrations spaced about $1 \mathrm{~cm}$ apart suggest that the banding is primary. 
Qôrqut pegmatites are conspicuous in the supracrustal belts because of their colour contrast. The supracrustal rocks are a common host because they occur in areas of downwarping with steeply developed fabrics controlling emplacement of pegmatites. The schlieric granites in contrast occur mainly in areas of uplift or doming.

Some rocks of the Qôrqut granite complex possess $S$ fabrics and it is their cross-cutting relationships with all the other established rock units rather than the lack of fabric that helps fix their position in the chronology.

\section{The Taserssuaq complex}

Most of the outcrop of the Taserssuaq pluton on the eastern side of Ilulialik is homogeneous tonalite with a poor discontinuous foliation. The intrusive margin is diffuse and contains xenoliths of orthogneiss and supracrustal rocks. The pluton is cut by north-south trending pegmatites and aplites, and by east-west trending MD dykes, some of which are sheared. The foliation in the tonalite is locally folded in a marginal zone.

On the western side of Ilulialik the pluton is different. It is multiphase with successive injections possibly being derived from an evolving magma system. Banding, textural variations, and younger injected sheets of varying compositions are prevalent. The texture varies from granular (less than $1 \mathrm{~mm}$ ) to porphyritic with feldspars $4 \mathrm{~cm}$ in length. Rock types range from leucogabbros through diorites, tonalites and trondhjemites to quartz-feldspar pegmatites. Patterns of xenoliths up to $3 \mathrm{~km}$ long demarcate large-scale folds. Banding of hornblende-biotite and more quartzo-feldspathic material is common and may be the result of metamorphic segregation under tectonic stress, or a relict fabric inherited from xenoliths of supracrustal rocks.

The earliest phases in the Taserssuaq pluton are broken up by tonalites and pegmatites but taken as a group they cover an area of about $3 \mathrm{~km}^{2}$. The coarsest type comprises euhedral to subhedral dark-green amphiboles about $1 \mathrm{~cm}$ across within a matrix of finer grained plagioclase. Pyroxene has not been seen. The finest grained types have $1 \mathrm{~mm}$ diameter, green amphiboles with finer plagioclase as a matrix. All types exhibit gravelly weathering. Contacts between these earliest phases and the tonalite and pegmatites are sharp. Most of these early phases are metagabbro.

More metagabbro is seen to the east of Ilulialik. It intrudes supracrustal amphibolite with a veined margin. Relations between it and the Amitsoq gneiss are ambiguous, but xenoliths of gneiss, presumed to be of Amitsoq affinity, are seen within the main gabbro body. The metagabbro is therefore younger than the Amitsoq gneiss but older than the Taserssuaq pluton since some tonalitic sheets cut it.

\section{Ultrabasic and ultramafic rocks}

Ultrabasic and ultramafic rocks occur in large mappable sheets and pods within Malene amphibolite units south of the central Ivisârtoq dome (fig. 26, CID). The distribution of the pods is such that they are considered to be disrupted parts of a few very large sheets, and because of this it is likely that these bodies have crystallised from basic to ultrabasic magmas. In many cases the host rocks are amphibolites which clearly are derived from pillow lavas, but at some localities a mass of metagabbro and/or homogeneous amphibolite forms a partial screen between the ultrabasic rock and the pillow structured amphibolite. 


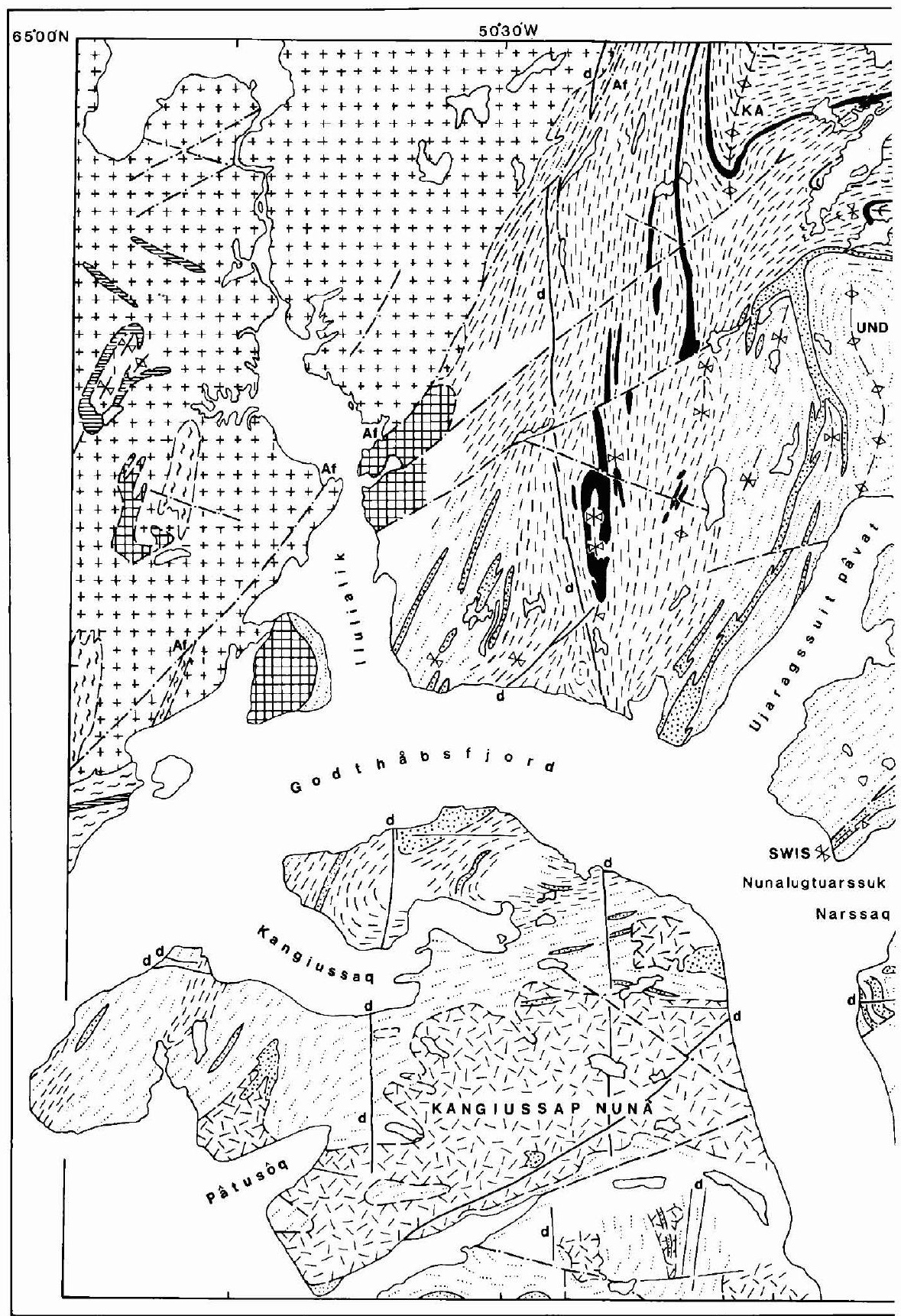

Fig. 26. Provisional geological map of the Ivisârtoq region. (1) Akilia (supracrustal) association; (2) Amîtsoq gneisses; (3) Malene supracrustal association; (4) Younging direction in pillowed amphibolites; (5) Gabbro-anorthosite complex; (6) Undifferentiated amphibolites; (7) Undifferentiated gneisses; (8) Nûk gneisses; (9) Synformal axial trace; KSS Kangilínguata sermia synform; SWIS Southwest Ivisârtoq 


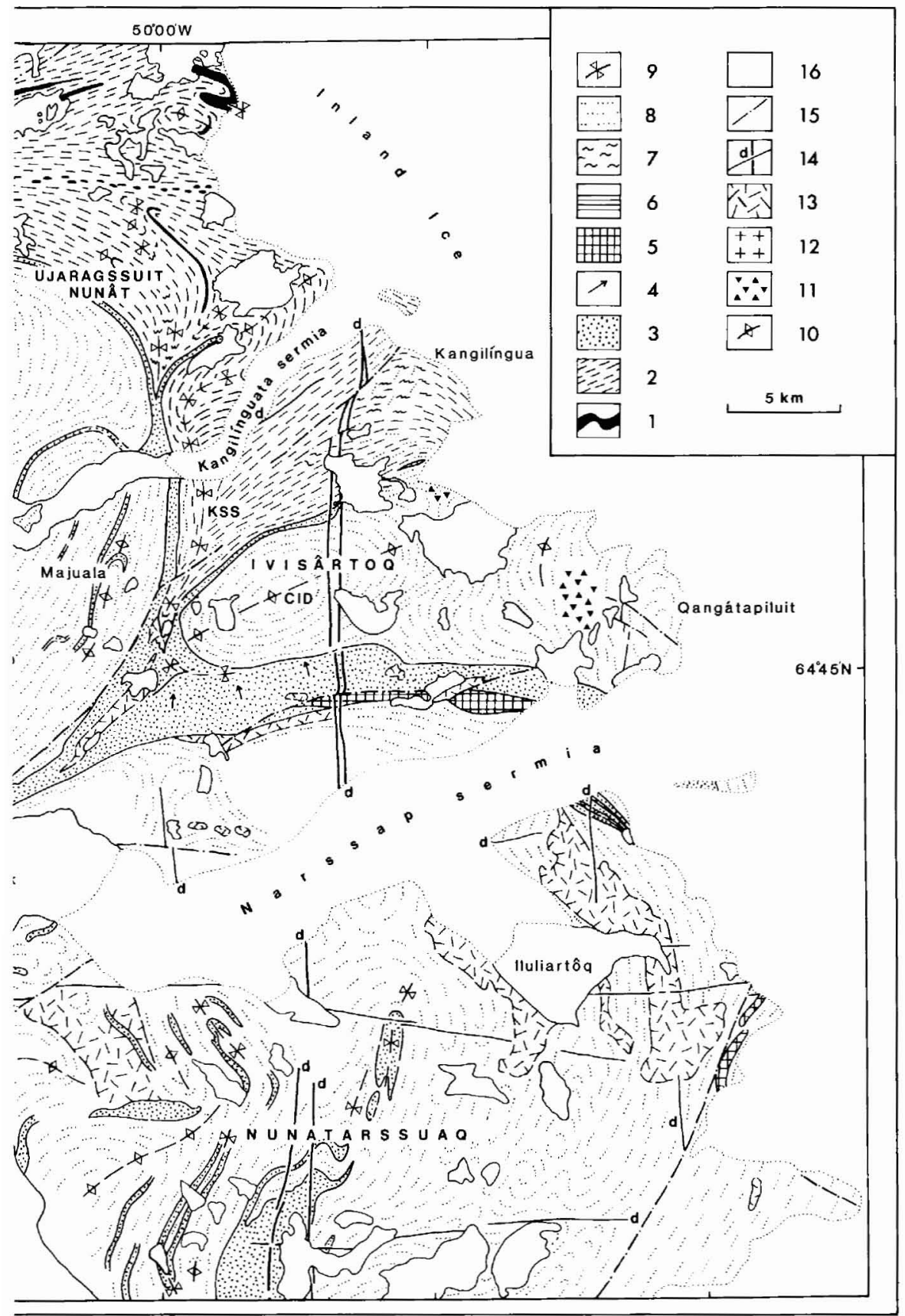

synform; (10) Antiformal axial trace; CID Central Ivisârtoq dome; UND Ujaragssuit nunât dome; (11) Sphene-bearing granitic rocks, Qangátapiluit; (12) Tasserssuaq complex; (13) Qôrqut granite and pegmatite; (14) MD dykes; (15) Fault, Af Ataneq fault; (16) Blank areas, not mapped or covered by superficial deposits. 
Significant relations are preserved between amphibolite and ultrabasic rocks in places. For instance, in the central part of the southern Malene belt an ultramafic body about $150 \mathrm{~m}$ broad has clear contacts with pillow lavas on its whole length (almost $1 \mathrm{~km}$ ) except at the east end where a pegmatite cuts across the contact. The ultramafic rock is very hard and fresh and appears when broken up to be tremolite rock, although the weathered rind has a nodular texture probably derived from large primocrysts (olivine or pyroxene?). Within this body are sheet-like inclusions between 1 and $5 \mathrm{~m}$ wide of an amphibolite type regarded as being derived from pillowed basalt. The contacts between the amphibolite and the ultramafic rock are parallel with the fabric in the amphibolite. The amphibolite masses therefore have the appearance of rafts in the ultramafic body which must be interpreted as a late sheet intrusion. Alternative interpretations, for instance that the contacts are faulted or that amphibolites were injected into the ultramafic rock, are not tenable. Faulting is not a possibility since no fault disturbance can be seen in the ultramafic rocks beyond the limit of the amphibolite. Injection of amphibolite is equally unacceptable if the protolith is taken to be (extruded) pillowed basalt.

In a second locality in circumstances where a fault contact can again be dismissed, the junction between the two units is sharp, with non-foliated ultramafic rock cutting discordantly across amphibolite banding.

The significance of these relations is that (a) the ultramafic rock must post-date the amphibolite, (b) it must be a sheet injection, and (c) since it cannot be cumulate rock, the injected melt must have been ultrabasic. In outcrops $c .550 \mathrm{~m}$ to the east which are probably part of the same sheet there are elongate crystals which in places are fragmented and have the appearance of a disrupted spinifex texture. This is, however, by no means certain.

Still farther to the east in a similar body pillow structures are preserved. These are very similar to the structures seen in amphibolites where the strain is low, but an important difference is that the exposed cross section of the pillows is distinctly smaller than that of the amphibolites, even where they are seen in their smallest section. The uncertainty about these exposures is not whether the rocks preserve pillow structures so much as whether they are ultrabasic. The lithology contrasts with the range of amphibolites in which pillows have been seen, but it is finer and more even grained than most ultrabasic rocks. The fresh rock is grey-green and it weathers to the typical drab khaki colour.

These observations support conclusions drawn by Hall (1981) about the former existence of ultrabasic magmas. They also suggest that these magmas may have given rise to sheet injections probably injected into amphibolites at shallow levels, locally erupting on to the ocean floor.

\section{Ameralik-like dykes}

The need for caution in identifying amphibolite dykes and attaching significance to them has been stressed recently (Brewer et al., 1983). The problem was again apparent during the 1983 field season when in two parts of Ivisârtoq observations were made on dykes which though having characteristics of Ameralik dykes clearly were injected after the formation of Nûk gneisses. The localities are in eastern Ivisârtoq, south-east Qangátapiluit and south-east Kangilíngua. Relationships in both areas are remarkably similar. The amphibolite dykes are closely similar to $\mathrm{C}$ type Ameralik dykes (Chadwick, 1981), having plagioclase clots with thin reaction rims concentrated near to one wall of the sheet. Fortunately, in the examples in 
question the host gneiss is multiphase and recognised as comprising Amitsoq gneiss with Ameralik dykes and sheets of Nûk gneiss. The Ameralik-like dykes are cut in turn by sparsely developed pegmatite which may be either a late Nûk phase or related to the Qôrqut granite. Thus they are either late intra-Nûk sheets or perhaps less likely, post-Nûk but preQôrqut in age. The similarity between these dykes in all cases extends to their relations with their hosts. They were injected into shear zones trending $c$. $045^{\circ}$ which were locally reactivated. On their north-west sides each dyke locally has sharp or transitional contacts with sheared amphibolite.

The particular host for these sheets makes an interpretation safe and relatively easy. If they had been found in homogeneous gneiss with no other dykes they would certainly have been interpreted as Ameralik dykes and their hosts as Amîtsoq gneisses.

\section{$M D$ and late acid dykes}

Thin acid dykes comparable to those in Isukasia described by Kalsbeek et al. (1980) and Kalsbeek \& Taylor (1983) have been mapped in two parts of Ivisârtoq. In the extreme east of Ivisârtoq (Qangátapiluit) a dyke was clearly emplaced into a series of brittle fractures in a branching form; the sheets have numerous splays and apophyses. In one locality a single sheet is $10 \mathrm{~m}$ wide, but in general the body is divided forming a zone which trends $120^{\circ}$ and can be traced in a straight outcrop for about $2 \mathrm{~km}$. At its westernmost point it cuts a northsouth trending MD dyke which is displaced by sinistral movement on faults also trending $120^{\circ}$. Chilled zones as described by Kalsbeek et al. (1980) are not obvious in the Ivisârtoq dyke complex which is fine grained throughout, so that macroscopic mineral determinations are not possible. The lithology is, however, much paler than that of members of the MD swarm of comparable grain size.

Other acid dykes in eastern Ivisârtoq have similar dimensions but trend $090^{\circ}$ and are in part coarse grained, being made up of quartz, two feldspars, and biotite with minor muscovite, and a sulphide mineral in a granular aggregate of $1 \mathrm{~mm}$ diameter grain size. Impersistent joint surfaces are lined with biotite grains. These dykes also cut north-south trending MD dykes.

Laboratory work is necessary to confirm that these bodies are of the same age and significance as the dyke from Isukasia.

North-south is a common trend for MD dykes in Ivisârtoq and dykes following that trend are the widest and hence the coarsest in texture. Their unusual mineralogy (the bodies tend to be noritic) has been described by Hall (1981) and this has been confirmed in the field, though it is perhaps significant that unlike some other major dolerites of about the same age they are variable, with a distinct range in the ratio of pyroxene to plagioclase. Moreover, some of the dykes are, at least in part, auto-amphibolitised probably due to magmatic injection into active shears, or to late faulting. The north-south trending bodies have been established as the earliest group of MD dykes and in Ivisârtoq they are cut by faults trending $080^{\circ}$ and $120^{\circ}$, in some cases with lateral displacement totalling little less than $1 \mathrm{~km}$. Fault zones are sometimes broad and in them the dykes and host rocks are strongly deformed and altered.

A dolerite dyke trending $080^{\circ}$ is unusual in showing multiple injection. The body has two or possibly three components totalling $10 \mathrm{~m}$ in width. The sections are equal in width with clear chilled margins between the outer two and the host rock which is a poorly banded 
biotite gneiss. The dykes are interesting because there are thin impersistent lenses of the biotite gneiss preserved between the outer and the inner units, with chilled margins on all contacts.

\section{Gneisses within the Ujaragssuit nunât dome (UND)}

Three major types of grey gneiss have been recognised within the large outcrops of this dome occupying the south of Ujaragssuit nunât and the tract including Majuala and Nunalugtuarssuq (fig. 26). The first type comprises migmatitic gneiss with strips and pods of homogeneous amphibolite and rare hornblendite and garnetiferous or biotite-rich paragneiss. It resembles the Nûk gneisses found widely throughout the Godthåbsfjord region.

The second type is a granitic or granodioritic biotite gneiss which commonly occurs in two main facies, one darker and one paler. In some outcrops the darker facies is the older phase, in others it is younger; generally it is less abundant and enclaves of amphibolite are rare. Thin, mainly concordant sheets of amphibolite with a few aggregates of feldspar like those in B type Ameralik dykes (Chadwick, 1981) were found in one outcrop. This type of gneiss appears to be restricted to a zone up to $1 \mathrm{~km}$ wide along the west and north-west of the Malene belt in the west of Ivisârtoq; it commonly has an intense $S$ fabric and may be described as a flaser rock. A ribbing lineation formed mainly by the elongation of quartz and feldspar is common on the $S$ fabric south-east of Majuala.

The third variety of gneiss is leucocratic and schlieric. It contains numerous scattered pods of homogeneous amphibolite and hornblendite. Thin biotite seams and schlieren form a relict foliation. Transitions visible in outcrop suggest this type formed by feldspar blastesis and/or partial melting, replacing the first and second varieties of gneiss. The schlieric gneiss is restricted mainly to the core of an antiform in the Majuala region which is interpreted as a parasitic structure on the eastern flank of the Ujaragssuit nunât dome (fig. 26; Chadwick et al., 1983). The schlieric gneiss is interpreted as having formed before the doming because the schlieric foliation is folded by numerous small-scale parasitic folds in the core of the Majuala antiform. The schlieric gneiss resembles that from the north of UND (Chadwick \& Crewe, 1982) for which S. Robertson (personal communication, 1983) has obtained a preliminary three-point $\mathrm{Rb}$-Sr whole rock isochron date of $2630 \mathrm{Ma}$. Whilst these gneisses may be correlated on the grounds of their field appearance and spatial relation within UND, more isotopic age data are needed before their age and origin can be fully understood in terms of the timing of the tectonic development of the Ivisârtoq region.

Coastal outcrops around the Majuala-Nunalugtuarssuk tract were not mapped, but nowhere in the outcrops mapped inland in 1983 in this part of UND is there unambiguous evidence of Ameralik dykes. This is at variance with Hall \& Friend's opinion (1979, fig. 1) and data on unpublished field sheets held by GGU which show occurrences of Ameralik dykes, and hence Amîtsoq gneisses. Whilst it is conceivable that some of the schlieric gneisses may be reworked Amîtsoq gneisses, preliminary isotopic age studies of a range of gneisses from the Majuala-Nunalugtuarssuk tract by S. Moorbath ( $\mathrm{Rb}-\mathrm{Sr}$, unpublished) and $\mathrm{S}$. Robertson $(\mathrm{Pb} / \mathrm{Pb}$, unpublished) have not revealed any positive evidence of exposed Amitsoq gneisses. The $\mathrm{Pb}$ isotope data plot in the same field on $\mathrm{a}^{207} \mathrm{~Pb} /{ }^{204} \mathrm{~Pb}$ against ${ }^{206} \mathrm{~Pb} /$ ${ }^{204} \mathrm{~Pb}$ diagram as Nûk gneisses contaminated by Amîtsoq-type $\mathrm{Pb}$ in Kangiussap nunâ ( $\mathrm{S}$. Robertson, personal communication, 1983) and elsewhere in the Godthåbsfjord region (Taylor et al., 1980). The absence of evidence for Amîtsoq gneisses has a bearing on the 
structural interpretation of a cliff section south-west of Majuala proposed by Hall \& Friend (1979, fig. 5).

\section{Sphene-bearing and other granitic rocks in Qangátapiluit}

The migmatitic orthogneisses in Qangátapiluit (fig. 26) are disrupted by intrusions of grey granite sensu lato with locally abundant, roughly ellipsoidal blebs or aggregates of white feldspar and quartz with cores of sphene (fig. 26). The aggregates are up to $3 \mathrm{~cm}$ in size and are commonly closely packed. Sphene in some leucocratic facies occurs as euhedral oikocrysts up to $2 \mathrm{~cm}$ long with numerous small inclusions of feldspar and quartz. Some of the intrusions are multiple with older, paler facies cut by younger, darker facies. Very rarely, the feldspar aggregates have cores of magnetite. Rocks with feldspar-magnetite aggregates are younger than the sphene-bearing granites. The sphene-bearing intrusions occur as broadly concordant or low-angle sheets a few metres thick, whilst others are discordant, irregular sheets which ramify through the host gneisses. On a small scale, the intrusions form anastomosing sheets around fragments of gneiss broken from the host. Fragments within the sheets appear to have been ductile during granite injection. Some fragments with diffuse boundaries may represent the early stages of digestion whose end product may be found in the biotitic schlieren of the granite sheets.

A biotite $S$ fabric parallel to contacts is common in the concordant sheets. The feldsparsphene aggregates have a preferred dimensional orientation parallel to the $S$ fabric. In many of the irregular sheets the biotite $S$ fabric has a variable orientation and the ellipsoidal feldspar-sphene aggregates have been deformed around the more rigid fragments of the host gneiss. In one sheet the feldspar-magnetite aggregates are elongated parallel to the axes of thin ptygmatic seams of magnetite-bearing pegmatite. These shape relations suggest the feldspar-sphene and the feldspar-magnetite aggregates were deformed during injection of the granites, from which it follows that the aggregates had a magmatic origin.

Other granitic rocks with biotite $S$ fabrics and locally coarse pegmatitic facies occur on the west of Qangátapiluit. They are largely barren of feldspar-sphene aggregates and have a more gneissic appearance because of the presence of thin, concordant and discordant stringers of pegmatite. They have a distinctive grey-pink weathering colour. Grey gneisses and amphibolites occur as xenoliths, some a few metres in size. Like the sphene-bearing granitic rocks, there are local schlieric lenses which may be relicts of completely digested host gneisses. The foliation in these granitic rocks and the host gneisses has local chaotic orientations which suggest that the grey-pink granites and perhaps the sphene-bearing granites may have been injected during a period of regional tectonic activity, i.e. intrusion may have been broadly contemporaneous with the formation of the domes in Qangátapiluit.

\section{Structure}

One of the principal aims of the 1983 mapping season was to pursue the model of the structure of the Ivisârtoq region as a dome and cusp system superimposed on an essentially horizontal complex of Amîtsoq gneisses and Malene supracrustal rocks interleaved on tectonic slides and massively intruded by Nûk gneisses. In this model which was outlined by Chadwick et al. (1983) the Amîtsoq gneisses in Kangilíngua and north-east Ujaragssuit nunât are regarded as having been thrust over a normal sequence of Malene supracrustal rocks 
(indicated by pillow structures) which was heavily injected and disrupted by Nûk gneisses contemporaneous with, or immediately following, the thrusting. That part of the Malene sequence which remained intact after this injection now forms the thick marker round the Ujaragssuit nunât dome and the regional structures on Ivisârtoq (fig. 26). The contacts between the Amitsoq gneisses and Malene rocks around the north-east of the Ujaragssuit nunât dome and within the Kangilínguata sermia synform are interpreted as being parts of a single tectonic slide formed during the thrusting event.

Within the core of UND immediately north-east of Ujaragssuit pâvat, all the gneisses appear to be of Nûk affinity because although thin sheets of amphibolite are common (as are pods and agmatites) no discordant amphibolites were found. Pegmatites of various generations are common. The earliest are concordant and appear to be related to early migmatisation of the gneiss and amphibolite. Some of these pegmatites are folded isoclinally on a small scale and are refolded by parasitic folds related to UND. Whilst the early isoclines are locally common, no evidence of large-scale isoclines older than UND was found, perhaps because of the lack of continuous amphibolite and other markers. Later pegmatites are related to coarsening of the gneiss by feldspar blastesis and partial melting, processes that appear to have taken place before and during the generation of UND. The original foliation of the gneisses is represented as biotite wisps in the coarsened pegmatitic gneiss. This later pegmatite with biotite wisps is in places deformed by small-scale folds parasitic on UND, but comparable pegmatites also occur coplanar with shear zones and axial surfaces of parasitic folds related to UND. These relations suggest the coarsening process continued into the period of UND development.

South-west of Majuala (fig. 26) a large $Z$ fold, marked by gneisses with locally abundant supracrustal enclaves, plunges gently south-west on the south-east limb of UND. This fold may be interpreted as having developed structurally above the gentle arc of the dome northeast of Ujaragssuit pâvat because of its asymmetry and plunge. The antiform whose axial trace passes north-north-east to south-south-west through Majuala plunges north-east, contrary to the regional south-west plunge of the $Z$ fold and ribbing lineation in most of the Majuala-Nunalugtuarssuk tract. The Majuala antiform (much of the core being occupied by schlieric gneiss) may be interpreted as a parasitic fold with a curved hinge on the south-east limb of UND. In order to accommodate the variable plunge of the regional coaxial folds and mineral lineation it is necessary to envisage displacement on tectonic slides contemporaneous with UND formation. One of these slides may occur on the boundary of the persistent thin sheet of heavily migmatised, Malene garnetiferous paragneiss west of Majuala. Another slide is assumed to occur within the gneisses to the south-east. Sliding is also believed to have taken place on the main Malene-orthogneiss contact on the inner arc of UND. This complex of slides, antiformal arcs and $Z$ folds in the area of Majuala may be attributed to the accommodation of gneisses and Malene rocks by disharmonic folding in a zone of strong compression between the closure of UND on Ujaragssuit nunât and the main Malene marker on the south-east limb of UND. The disharmonic folding in the Majuala area and in the area of the mud flats forming the outwash of Kangilinguata sermia, probably necessitated sliding (flexural slip) broadly parallel to the gneiss foliation and the concordant Malene amphibolite markers on Ujaragssuit nunât. The disharmonic folding may account for some of the complexities and thickening in the Malene rocks north of the outwash.

Mylonites which occur along parts of the contact between the flaser orthogneisses and the main Malene amphibolite marker on the south-east limb of UND in west Ivisârtoq appear to 
be related to the dome and cusp deformation and younger faulting. Malene amphibolites and paragneisses in the extreme south-west of Ivisârtoq, i.e. in the core of the postulated synform (fig. 26, SWIS), the south-west Ivisârtoq dome (Chadwick et al., 1983), are intensely sheared and mylonitised with much epidotisation and bleaching. This intense deformation is consistent with the interpretation of this part as a cusp between the south-east of UND and a major area of uplift occupied by Nûk gneisses in south Ivisârtoq and north Nunatarssuaq. The Nûk gneisses in south Ivisârtoq appear to form a system of domes whose boundary with the main Malene tract to the north is marked by intense shearing and mylonitisation.

The dome in central Ivisârtoq (fig. 26, CID; Chadwick et al., 1983) is an elongate pericline with a horizontal crest and increasing plunge to the west-south-west and east-north-east. The southern limb steepens to vertical, apparently as part of a large shear zone in the gneisses between the central Ivisârtoq dome and other smaller domes in Qangátapiluit. The central Ivisârtoq dome and Qangátapiluit domes appear to be parts of a domes within a dome system occupying the eastern part of Ivisârtoq. The domes in south Ivisârtoq may also be part of a similar domes within a dome system.

The regional ribbing and mineral lineation which is coaxial with folds in many parts of the dome and cusp system in the Ivisârtoq region varies in intensity and direction, the variation being most marked within the Malene rocks of Ivisârtoq. Reasons for this variation will be discussed elsewhere. The lineation can be interpreted as a finite maximum extension on the grounds that it is parallel to the maximum shape elongation of feldspar aggregates in Ameralik dykes, pillow structures in Malene amphibolites, and quartz-feldspar aggregates in some orthogneisses. That the lineation formed during the dome and cusp phase of deformation is indicated by its occurrence in Nûk granite sheets and pegmatites coplanar with parasitic folds in the Kangilínguata sermia synform (fig. 26, KSS; Chadwick et al., 1983). In these sheets the $L$ fabric formed with an $S$ fabric, although in most of the Ivisârtoq region $S$ fabrics do not appear to have developed widely in the dome and cusp phase. More intense $S$ fabrics, for example penetrative fabrics and banding in Malene amphibolites and ultramafic rocks, were formed during the tectonic interleaving of the Amitsoq gneisses and Malene supracrustal rocks and the injection of the bulk of the Nûk gneisses prior to the dome and cusp phase.

The disharmonic folding of the early $S$ fabric and the concordant orthogneisses and Malene markers in the Ujaragssuit nunât dome and the presence of the finite extension lineation coaxial with folds suggests that the domes and cusps in the Ivisârtoq region did not form by a simple diapiric mechanism, but must have involved regional compressions. Possible mechanisms will be discussed elsewhere.

Fractures which include faults and joints are common in the Ivisârtoq region and in many parts the orthogneisses and supracrustal rocks are heavily epidotised and reddened. The most detailed study of fracture systems has been undertaken in the north-west of the region, with particular attention being given to the Ataneq fault (fig. 26). Two main types of fault have been distinguished on the basis of displacements and fault-rock textures.

Faults of the first type are thrusts which are prominent east of Ilulialik (fig. 26). The thrust planes trend north-south and dip about $40^{\circ}$ east. Slickencrysts in platy quartz mylonites indicate thrusting from east to west with the slip vector pitching $70^{\circ}$ to $80^{\circ}$ south. Fissile quartz mylonites with thin seams of epidote and mica occur as sheets $1-2 \mathrm{~cm}$ thick in wider tracts of protomylonite formed by intensely sheared quartzo-feldspathic gneisses and dis- 
rupted quartz-feldspar pegmatites. Sheets of grey orthogneiss believed to be of Nûk affinity are deformed by the thrusts, but other possible Nûk gneiss sheets cut the thrusts. The orientation of the thrusts suggests east-west compression. Their apparent time relations with Nûk intrusive activity and the overthrusting from the east suggest that the thrusts may be related to the formation of the dome and cusp system in the east of the region.

The second type of fault is mainly sub-vertical and has two main trends, one east-northeast and the other east-south-east. The faults may be interpreted as a conjugate strike slip system because their slip vectors are approximately horizontal. Deformation was less ductile than that in the thrusts, although diffusive mass transfer and localised mylonitisation processes were probably important. MD dykes are sheared and amphibolitised and gneisses are enriched in quartz close to and within the fault zones. Feldspars may be reddened and quartz-epidote veins are common. The conjugate fault system is believed to have formed before mid-Proterozoic times since acid dykes in east Ivisârtoq which cut north-south MD dykes may be mid-Proterozoic in age like the granite dyke in Isukasia dated by Kalsbeek \& Taylor (1983; see also earlier in this report). It is conceivable that the conjugate fault system in Ivisârtoq and adjacent regions developed as part of the Proterozoic continental collision which is believed by Watterson (1978) to have given rise to the Nagssugtoqidian and Ketilidian mobile belts.

The Ataneq fault is interpreted as a thrust which was generated early like the other thrusts east of Ilulialik and later reactivated as part of the conjugate fault system. Dextral strike-slip displacements of $4 \mathrm{~km}$ on the Ataneq fault during this reactivation are indicated by offsets of a north-south MD dyke (fig. 26) and the boundary between the Taserssuaq complex and its host gneisses.

Acknowledgements. Exeter teams along with two other GGU parties were serviced by a helicopter contracted from Grønlands Air Charter A/S with its work co-ordinated by the GGU cutter $K . J . V$. Steenstrup. We wish to acknowledge our great debt to D. Pedersen of Grønlands Air Charter A/S and Flemming Nielsen, skipper of $K . J$. V. Steenstrup, who succeeded in providing safe and reliable support throughout what was one of the worst summers on record.

\section{References}

Brewer, M., Coe, K. \& Robertson, S. 1983: Continuation of the mapping of Archaean rocks in the southern part of the Ivisârtoq map sheet. Rapp. Grønlands geol. Unders. 115, 42-48.

Chadwick, B. 1981: Field relations, petrography and geochemistry of Archaean amphibolite dykes and Malene supracrustal amphibolites, Northwest Buksefjorden, southern West Greenland. Precambrian Res. 14, 221-259.

Chadwick, B. \& Crewe, M. A. 1982: Field work in the Ujaragssuit nunât area, Ivisârtoq region, inner Godthåbsfjord, southern West Greenland. Rapp. Grønlands geol. Unders. 110, 57-63.

Chadwick, B., Crewe, M. A. \& Park, J. F. W. 1983: Field work in the north of the Ivisârtoq region, inner Godthåbsfjord, southern West Greenland. Rapp. Grønlands geol. Unders. 115, 49-56.

Coe, K. \& Robertson, S. 1982: Mapping of Archaean rocks in part of the Ivisârtoq sheet. Rapp. Grønlands geol. Unders. 110, 63-67.

Hall, R. P. 1980: The tholeiitic and komatiitic affinities of Malene metavolcanic amphibolites from Ivisârtoq, southern West Greenland. Rapp. Grønlands geol. Unders. 97, 20 pp.

Hall, R. P. 1981: The Archaean geology of Ivisârtoq, inner Godthåbsfjord, southern West Greenland. Unpubl. Ph. D. thesis, Committee for National Academic Awards, U. K.

Hall, R. P. \& Friend, C. R. L. 1979: Structural evolution of the Archaean rocks in Ivisârtoq and the neighbouring inner Godthåbsfjord region, southern West Greenland. Geology 7, 311-315. 
Kalsbeek, F. \& Taylor, P. N. 1983: Anatectic origin of mid-Proterozoic granite dyke in the Isukasia area, West Greenland. $\mathrm{Pb}-\mathrm{Pb}$ and $\mathrm{Rb}-\mathrm{Sr}$ isotope evidence. Rapp. Grønlands geol. Unders. 115, 38-42.

Kalsbeek, F., Bridgwater, D. \& Boak, J. 1980: Evidence of mid-Proterozoic granite formation in the Isua area. Rapp. Grønlands geol. Unders. 100, 73-75.

Nutman, A. P. 1982: Further work on the early Archaean rocks of the Isukasia area, southern West Greenland. Rapp. Grønlands geol. Unders. 110, 49-54.

Taylor, P. N., Moorbath, S., Goodwin, R. \& Petrykowski, A. C. 1980: Crustal contamination as an indicator of the extent of early Archaean continental crust: $\mathrm{Pb}$ isotope evidence from the late Archaean gneisses of West Greenland. Geochim. cosmochim. Acta 44, 1437-1454.

Watterson, J. 1978: Proterozoic intra-plate deformation in the light of S. E. Asian neotectonics. Nature, Lond. 273, 636-640.

Department of Geology, The University, Exeter EX4 4QE, U.K.

\title{
Textures of Archaean granites, Ivisârtoq region, southern West Greenland
}

\author{
Steven Robertson
}

Granite textures are widely believed to reflect the effect of extensive subsolidus (i.e. postmagmatic) recrystallisation. Detailed thin section observations of Archaean granites from the Ivisârtoq map sheet area, however, have revealed that subsolidus recrystallisation may by very limited. These observations apply to Qôrqut Granite Complex, 2610 Ma granites (Robertson, 1983) and Nûk granites from north-east Ivisârtoq. They all contain modal quartz, plagioclase and microcline in approximately equal proportions, with variable amounts of biotite ranging up to a maximum of $12 \%$ of the total. Accessory mineral phases include zircon, apatite, allanite, sphene, ilmenite, magnetite and occasionally pyrite. Textural relations suggest that the accessory phases crystallised at an early stage in the evolution of the granites and all appear to predate biotite, the earliest of the major minerals.

If any meaningful magmatic relationships are to be observed between the felsic minerals, then post-magmatic recrystallisation must be limited to grain boundaries. This is supported by the following observations of plagioclase-microcline grain boundaries. Plagioclase, where in contact with microcline, generally has a marginal zone of different optical orientation and/ or composition. This zone may, or may not be myrmekitic. Locally, the two types of zone occur at the same grain boundary, in which case the non-myrmekitic zone always rims the myrmekitic zone. The most common occurrence of the myrmekitic zones is as convex lobes penetrating into microcline with the microcline appearing to be a late crystallising phase. Myrmekite at planar plagioclase-microcline boundaries usually occurs in much thinner zones than those of the lobate myrmekite. Locally up to three distinct myrmekitic zones are developed on the same grain boundary (fig. 27). The dimensions of the quartz vermicules 